\title{
Simulation of boron and carbon fiber composite characteristics of the elasticity
}

\author{
Victor.P. Pavlov ${ }^{1}$, Vilina. M. Kudoyarova ${ }^{2, *}$, and Alexander. A. Philippov ${ }^{1}$ \\ ${ }^{1}$ Ufa State Aviation Technical University, Chair of Strength of Materials, st. K. Marcsa,12, Ufa, 450000, Russian Federation \\ ${ }^{2}$ Ufa State Aviation Technical University, Chair of Aviation Thermal and Energy Engineering, st. K. Marcsa, 12, Ufa, 450000, Russian \\ Federation
}

\begin{abstract}
The use of hybrid fiber-reinforced polymer composites (FRP) opens up wide possibilities for creating structures that are most suitable for different operating conditions. The modelling of a multilayer FRP structure is the most important stage in the creation and manufacture of FRP products since the FRP structure determines the entire complex of elastic, strength and other properties. This paper proposes a method for the theoretical prediction of anisotropic elastic characteristics of material equivalent to a given FRP. A technique for calculating the stiffness coefficients of a homogeneous anisotropic material equivalent to a hybrid composite material having a magnesium matrix reinforced with boron and carbon fibers has been developed and tested in ANSYS. This paper has found that the results of the finite element analysis essentially depend on the dimension of the mesh, and it is necessary to use a mesh with a number of nodes exceeding $N=1 \cdot 10^{5}$ to obtain sufficiently accurate calculated values of the elasticity coefficients.
\end{abstract}

\section{Introduction}

The FRP of two or more kinds of reinforcing fibers are widely used in modern technology-based products, e.g. boron and carbon fibers. For the strength and stiffness calculation, an equivalent homogeneous anisotropic material usually replaces the heterogeneous FRP, for which the mechanical properties will be determined [112].

The experimental simulation of properties FRP composites is very time-consuming [13-19], and a wide variety of structures FRP composites does not allow to study the characteristics for all possible variants. Therefore, computer simulation of the mechanical characteristics FRP materials for its various structures is very promising [8-12].

Two problems arise:

- What do we take as an equivalence for considering heterogeneous FRP composite and for homogeneous anisotropic material?

- How do we determine the effective elasticity characteristics of an equivalent anisotropic material?

It should be noted that there is no unequivocal solution of these problems, and each researcher can realize his own path.

This paper considers a technique for mathematical modeling of the elasticity characteristics of FRP having carbon and boron fibers, based on the FEM using ANSYS.

The proposed work solves the mathematical modeling problem of the elasticity characteristics FRP composite having carbon and boron fibers. The finite element method (FEM) is implemented by using the ANSYS.

\section{Problem definition}

The paper considers a FRP composite with a given mechanical characteristics (matrix and reinforcement) and orientation of the fibers.

This paper builds the theoretical prediction task of the anisotropic elastic material characteristics that are equivalent to the FRP composite. An equivalent material is considered to be obeying to the linear Hooke's law [20].

\section{Formation a FRP Composite Representative Element}

In order to predict the mechanical characteristics of the hybrid FRP, it is necessary to specify its structure and the mechanical characteristics of its components.

The real FRP structure has a significant indeterminacy which is associated with the fact that FRP consists of many fibers of small diameter, and it is almost impossible to dispose the fibers by a uniquely defined law. We can only orient the fiber's threads in space as a whole and even then not with absolute exactness. In addition, the fibers combined into the FRP thread will be located at different distances unknown for each individual thread.

It is possible to determine the average direction for the fiber bundle in the space and also determine the

\footnotetext{
* Corresponding author: Kudoyarova@inbox.ru
} 
proportions of one or the other type fiber in the volume of hybrid FRP by studying the structure and composition of hybrid FRP experimentally.

Thus, we have assumed that we knew the directions of the reinforcing threads and the coefficients of their concentration in the considering volume of hybrid FRP. Based on this, we are applying some idealization and forming the representative element for FRP composite based on magnesium binder reinforced with carbon and boron fibers to calculate its effective elastic characteristics. It has a rectangular prism form with $a_{x}$, $a_{y}, a_{z}$ side dimensions and contains a single boron fiber $d_{B}=100$ mic diameter, fourteen carbon fibers $d_{C}=10$ mic diameter. Boron fiber is oriented along to $Y$-axis, carbon fibers are directed along $X$-axis (Fig. 1).
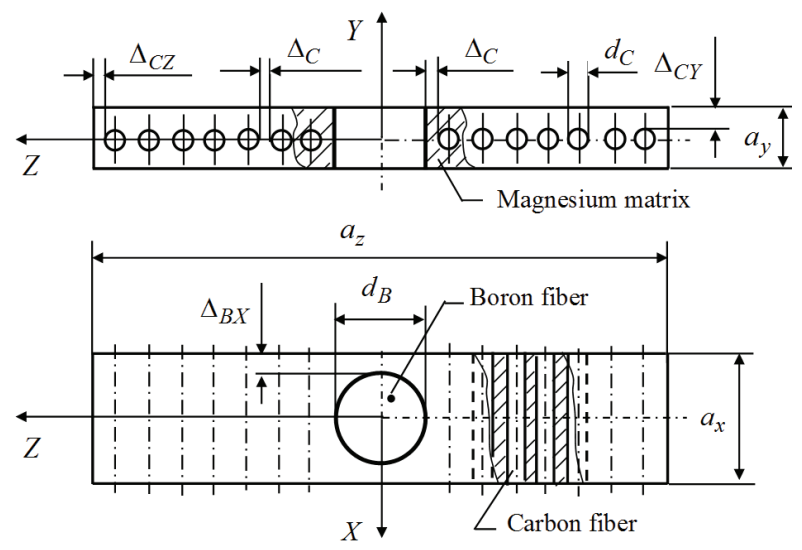

Fig. 1. Representative element for FRP composite

The distance between adjacent carbon fibers along the $Y$ - axis and the minimum distance between boron and carbon fibers equals to $\Delta_{C}=2 \mathrm{mic}$ (fig. 1). The minimum distances from the carbon fibers to the side faces of the representative element that is perpendicular to the $\mathrm{Y}$-axis and $\mathrm{Z}$-axis are equal to $\Delta_{C Y}=1 \mathrm{mic}$ and $\Delta_{C Z}=1$ mic, respectively, (fig. 1). The distance from the boron fiber to the side faces of the representative element that is perpendicular to the $\mathrm{X}$-axis equals to $\Delta_{B X}$ $=5$ mic (fig. 1).

In accordance with fig. 1 the representative element has the following sizes: $a_{x}=1,1 \cdot 10^{-4} \mathrm{~m}, a_{y}=1,2 \cdot 10^{-5} \mathrm{~m}$, $a_{z}=2,7 \cdot 10^{-4} \mathrm{~m}$.

We define for a representative element of the hybrid FRP for the indicated dimensions: total volume $V$, volume of the carbon component $V_{C}$, volume of the boron component $V_{B}$ :

$$
\left\{\begin{array}{l}
V=a_{x} a_{y} a_{z}=3,56 \cdot 10^{-13} \mathrm{~m}, \\
V_{C}=14 \pi d_{C}^{2} a_{x} / 4=1,21 \cdot 10^{-13} \mathrm{~m}, \\
V_{B}=\pi d_{B}^{2} a_{y} / 4=9,42 \cdot 10^{-14} \mathrm{~m} .
\end{array}\right.
$$

On the basis of these expressions, we determine the volume coefficients of FRP reinforcement by carbon $\left(\Psi_{C}\right)$ and boron $\left(\Psi_{B}\right)$ fibers:

$$
\left\{\begin{array}{l}
\Psi_{C}=\frac{V_{C}}{V}=0,339 \\
\Psi_{B}=\frac{\Psi_{B}}{\Psi}=0,264 .
\end{array}\right.
$$

The FRP reinforcement ratio for carbon fibers equal to $\Psi_{C}=0,339$ and for boron fibers equal to $\Psi_{B}=0,264$.

\section{Modeling the elasticity characteristics of FRP composite by using FEM}

This paper considers a homogeneous anisotropic material is accepted as the equivalent for the FRP with the relationship between stresses $\sigma_{x}, \sigma_{y}, \sigma_{z}, \tau_{x y}, \tau_{y z}, \tau_{x z}$ and deformations $\varepsilon_{x}, \varepsilon_{y}, \varepsilon_{z}, \gamma_{x y}, \gamma_{y z}, \gamma_{x z}$ that is determined by six relations [20]:

$$
\left\{\begin{array}{l}
\sigma_{x}=E_{11} \varepsilon_{x}+E_{12} \varepsilon_{y}+E_{13} \varepsilon_{z}+E_{14} \gamma_{x y}+E_{15} \gamma_{y z}+E_{16} \gamma_{x z}, \\
\sigma_{y}=E_{21} \varepsilon_{x}+E_{22} \varepsilon_{y}+E_{23} \varepsilon_{z}+E_{24} \gamma_{x y}+E_{25} \gamma_{y z}+E_{26} \gamma_{x z}, \\
\sigma_{z}=E_{31} \varepsilon_{x}+E_{32} \varepsilon_{y}+E_{33} \varepsilon_{z}+E_{34} \gamma_{x y}+E_{35} \gamma_{y z}+E_{36} \gamma_{x z}, \\
\tau_{x y}=E_{41} \varepsilon_{x}+E_{42} \varepsilon_{y}+E_{43} \varepsilon_{z}+E_{44} \gamma_{x y}+E_{45} \gamma_{y z}+E_{46} \gamma_{x z}, \\
\tau_{y z}=E_{51} \varepsilon_{x}+E_{52} \varepsilon_{y}+E_{53} \varepsilon_{z}+E_{54} \gamma_{x y}+E_{55} \gamma_{y z}+E_{56} \gamma_{x z}, \\
\tau_{x z}=E_{61} \varepsilon_{x}+E_{62} \varepsilon_{y}+E_{63} \varepsilon_{z}+E_{64} \gamma_{x y}+E_{65} \gamma_{y z}+E_{66} \gamma_{x z},
\end{array}\right.
$$

The stiffness coefficients of the equivalent material $E_{i j}, i, j=\overline{1,6}$ are determined on the basis of mathematical modeling of the deformation for a FRP representative element at six numerical experiments, in each of which only one of the strain components differs from zero.

In the first experiment $\varepsilon_{x} \neq 0, \varepsilon_{y}=\varepsilon_{z}=\gamma_{x y}=\gamma_{y z}=\gamma_{x z}$ $=0$. For this case the deformation of the representative element is shown in Fig. 2.

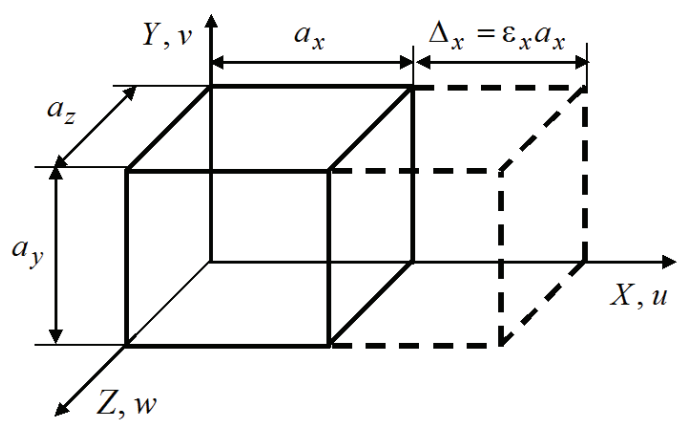

Fig. 2. Linear deformation of a representative element along the $X$-axis

For all three faces of the FRP representative element the averaged stresses $\bar{\sigma}_{x}^{(\varepsilon x)}, \bar{\sigma}_{y}^{(\varepsilon x)}, \bar{\sigma}_{z}^{(\varepsilon x)}, \bar{\tau}_{x y}^{(\varepsilon x)}, \bar{\tau}_{y z}^{(\varepsilon x)}, \bar{\tau}_{x z}^{(\varepsilon x)}$ at given deformation are determined in ANSYS. The expressions of stiffness coefficients: $E_{11}=\bar{\sigma}_{x}^{(\varepsilon x)} / \varepsilon_{x}$, $E_{21}=\bar{\sigma}_{y}^{(\varepsilon x)} / \varepsilon_{x}, \quad E_{31}=\bar{\sigma}_{z}^{(\varepsilon x)} / \varepsilon_{x}, \quad E_{41}=\bar{\tau}_{x y}^{(\varepsilon x)} / \varepsilon_{x}$, $E_{51}=\bar{\tau}_{y z}^{(\varepsilon x)} / \varepsilon_{x}, \quad E_{61}=\bar{\tau}_{x z}^{(\varepsilon x)} / \varepsilon_{x}$ were obtained under substituting of averaged stresses in the first three equations of the system (1).

Similarly, the elasticity coefficients $E_{i 2}, i=\overline{1,6}$ and 
$E_{i 3}, i=\overline{1,6}$ of an equivalent anisotropic homogeneous material are determined by specifying the deformation components different from zero $\varepsilon_{y} \neq 0$, and then $\varepsilon_{z} \neq 0$.

To determine the stiffness characteristics under shear the deformation of the representative element under shear strain $\gamma_{x y} \neq 0, \varepsilon_{x}=\varepsilon_{y}=\varepsilon_{z}=\gamma_{y z}=\gamma_{x z}=0$ is considered (fig. 3), in which the averaged stresses $\bar{\sigma}_{x}^{(\varepsilon x)}, \bar{\sigma}_{y}^{(\varepsilon x)}, \bar{\sigma}_{z}^{(\varepsilon x)}, \bar{\tau}_{x y}^{(\varepsilon x)}, \bar{\tau}_{y z}^{(\varepsilon x)}, \bar{\tau}_{x z}^{(\varepsilon x)}$ are calculated, and then the corresponding elasticity coefficients $E_{i 4}, i=\overline{1,6}$ are also calculated.

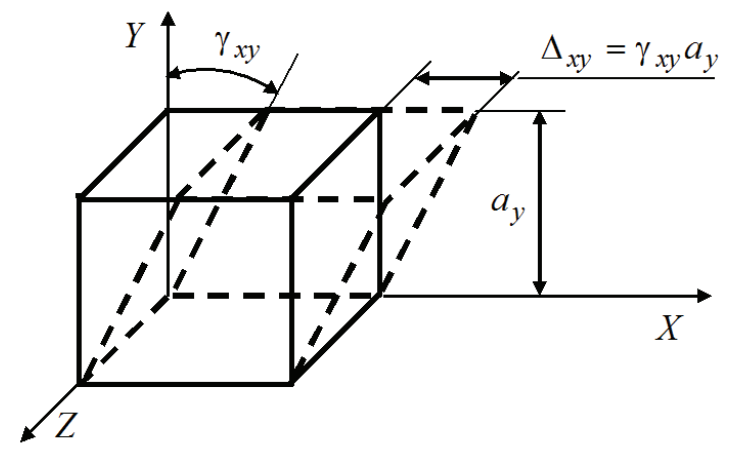

Fig. 3. Shear strain of the material of a representative element on the $X Y$-plane

Then, the elasticity coefficients $E_{i 5}, i=\overline{1,6}$ and $E_{i 6}, i=\overline{1,6}$ are determined by specifying deformation components different from zero $\gamma_{y z} \neq 0, \gamma_{x z} \neq 0$.

\section{Results}

According to the proposed method, the FRP stiffness characteristics under consideration are calculated, assuming that the FRP reinforcing components and FRP matrix components are isotropic materials with modulus of elasticity $E$ and Poisson's coefficient $v$.

At the same time, we take into account that the physical-mechanical characteristics of carbon and boron fibers, which are given in the literature, have a very wide dispersion related to the specific technology of their production, and therefore we take for them the following values of mechanical characteristics averaged from the literature sources $[1,5]$ :

- The matrix made of the alloy ML-10 has $\rho_{a}=1800$ $\mathrm{kg} / \mathrm{m}^{3}, E_{a}=0,44 \cdot 10^{11} \mathrm{~Pa}, v_{a}=0,28, \sigma_{a}{ }^{\text {us }}=245 \mathrm{MPa}$,

- Carbon reinforcing fibers have: $\rho_{C}=1800 \mathrm{~kg} / \mathrm{m}^{3}, E_{C}=$ $3 \cdot 10^{11} \mathrm{~Pa}, v_{C}=0,2, \sigma_{C}{ }^{\text {us }}=2000 \mathrm{MPa}$,

- Boron reinforcing fibers have: $\rho_{B}=2500 \mathrm{~kg} / \mathrm{m}^{3}, E_{B}=$ $4 \cdot 10^{11} \mathrm{~Pa}, v_{B}=0,25, \sigma_{B}{ }^{\text {us }}=3000 \mathrm{MPa}$.

The following non-zero values of the stiffness coefficients for the FRP composite $E_{i j}$ have been obtained as a calculation results:

$$
\left\{\begin{array}{lll}
E_{1,1}=1,41 \cdot 10^{11}, & E_{1,2}=2,92 \cdot 10^{10}, & E_{1,3}=4,60 \cdot 10^{10}, \\
E_{2,1}=2,92 \cdot 10^{10}, & E_{2,2}=5,90 \cdot 10^{10}, & E_{2,3}=4,49 \cdot 10^{10}, \\
E_{3,1}=4,60 \cdot 10^{10}, & E_{3,2}=4,49 \cdot 10^{10}, & E_{3,3}=1,81 \cdot 10^{11}, \\
E_{4,4}=7,02 \cdot 10^{9}, & E_{5,5}=7,45 \cdot 10^{9}, & E_{6,6}=8,07 \cdot 10^{9} .
\end{array}\right.
$$

The remaining stiffness coefficients are equal to zero in view of the presence of FPR composite's plane symmetry.

\section{Conclusion}

1. The representative element structure of a hybrid FRP composite based on a magnesium matrix reinforced with boron and carbon fibers is proposed.

2. A technique for calculating the stiffness coefficients of a homogeneous anisotropic material equivalent to a hybrid composite material having a magnesium matrix reinforced with boron and carbon fibers has been developed and tested by using FEM in ANSYS.

3. It is found that the results of the finite element analysis essentially depend on the dimension of the mesh, and it is necessary to use a mesh with a number of nodes exceeding $N=1 \cdot 10^{5}$ to obtain sufficiently accurate calculated values of the elasticity coefficients.

\section{References}

1. Yu. S. Pervushin, Proektirovanie i prognozirovanie mekhanicheskih svojstv odnonapravlennogo sloya iz kompozicionnogo materiala (Designing and predicting the mechanical properties of a unidirectional composite material). (Ufa: UGATU, 2002). (in Russ.)

2. I. G. Zhigun, V. A. Polyakov, Svojstva prostranstvenno-armirovannyh plastikov (Properties of spatially reinforced plastics). (Riga: Zinatne, 1978). (in Russ.)

3. V. V. Vasil'ev, Mekhanika konstrukcij iz kompozicionnyh materialov (Mechanics of composite structures). (M.: Mashinostroenie, 1988). (in Russ.)

4. Kompozicionnye materialy: Spravochnik (Composite materials: Handbook) (M.: Mashinostroenie, 1990). (in Russ.)

5. Yu. A. Mikhajlin, Konstrukcionnye polimernye kompozicionnye materialy (Structural polymeric composite materials) ( $\mathrm{SPb} .:$ Nauchnye omsnovy i tekhnologii, 2008). (in Russ.)

6. S. A. Lur'e, Yusefi Shakhram, Mekhanika kompozicionnykh materialov i konstrukcij. vol. 3, № 4, pp. 76-92 (1996). (in Russ.)

7. Spravochnik po kompozicionnym materialam (Handbook of Composite Materials). (M.: Mashinostroenie, 1988). (in Russ.)

8. Yu. I. Dimitrienko, A. P. Sokolov, Vestnik MGTU im. N. E. Baumana. Ser. Estestvennye nauki, №2, pp. 57 - 67 (2008). (in Russ.)

9. Yu. I. Dimitrienko, A. P. Sokolov, Vestnik MGTU im. N. E. Baumana. Ser. Estestvennye nauki, №2. pp. 56-67 (2008). (in Russ.)

10. Yu. I. Dimitrienko, A. P. Sokolov, Informacionnye tekhnologii, № 8. pp. 31 - 38, (2008). (in Russ.)

11. Ju.I. Dimitrienko, A.I. Kashkarov, Konechno- 
jelementnyj metod dlja vychislenija jeffektivnyh harakteristik prostranstvenno-armirovannyh kompozitov, Vestnik MGTU im. N.Je. Baumana. Ser. Estestvennye nauki № 2, pp. 95-108 (2002). (in Russ.)

12. Yu. I. Dimitrienko, A. P. Sokolov, A. I. Kashkarov, Aehrokosmicheskie tekhnologii. M.: MGTU im. N. E. Baumana, pp. 113 - 114 (2004). (in Russ.)

13. E. K. Ashkenazi, E. V. Ganov, Anizotropiya konstrukcionnykh materialov: Spravochnik (Anisotropy of structural materials: Handbook). (L.: Mashinostroenie, 1972). (in Russ.)

14. Kompozicionnye materialy. T. 2. Mekhanika kompozicionnym materialov (Composite materials. vol. 2. Mechanics of composite materials). (M.: Mir, 1978). (in Russ.)

15. Kompozicionnye materialy. T. 7. Analiz $i$ proektirovanie konstrukcij (Composite materials. vol. 7. Analysis and design of structures). (M.: Mashinostroenie, 1978). (in Russ.)

16. Yu. M. Tarnopol'skij, I. G. Zhigun, V. A. Polyakov, Prostranstvenno-armirovannye kompozicionnye materialy: Spravochnik (Spatially-reinforced composite materials: Handbook). (M.: Mashinostroenie, 1987). (in Russ.)

17. Yu. V. Sokolkin, A. A. Tashkinov. Mekhanika deformirovaniya $i$ razrusheniya strukturno neodnorodnykh tel (Mechanics of deformation and destruction of structurally heterogeneous bodies). (M.: Nauka, 1984). (in Russ.)

18. V. P. Pavlov, Polzuchest' polimernykh kompozicionnykh materialov pri peremennykh povyshennykh temperaturakh. Eksperimental'nye issledovaniya $i$ matematicheskoe modelirovanie (Creep of polymer composite materials at variable elevated temperatures. Experimental research and mathematical modeling). (Ufa: Ufimsk. gos. aviac. tekhn. un-t, 2004). (in Russ.)

19. V. P. Pavlov, Teplovaya deformaciya, prochnost' $i$ termovyazkouprugost' stekloplastikov pri vysokoj peremennoj vo vremeni temperature $v$ usloviyakh termodestrukcii. Eksperimental'nye issledovaniya i matematicheskoe modelirovanie (Thermal deformation, strength and thermal viscoelasticity of GRP at a high temperature-variable temperature under thermal destruction conditions. Experimental research and mathematical modeling). (Ufa: Ufimsk. gos. aviac. tekhn. un-t, 2004). (in Russ.)

20. S. G. Lekhnickij, Teoriya uprugosti anizotropnogo tela (Theory of elasticity of an anisotropic body). (M.: Nauka, 1977). (in Russ.) 